\title{
Teacher Behavior Checklist: Psychometric Evidence in Teacher Evaluation by Brazilian University Students
}

\author{
Marcelo Henrique Oliveira Henklain ${ }^{1}$ \\ João dos Santos Carmo ${ }^{2}$ \\ Verônica Bender Haydu ${ }^{3}$ (D) \\ Monalisa Muniz ${ }^{2}$ \\ William Buskist ${ }^{4}$ (iD \\ Jared Wayne Keeley ${ }^{5}$ iD
}

\begin{abstract}
Performance evaluations help university teachers to improve teaching, especially when based on internationally recognized criteria. This study aimed to carry out a cross-cultural adaptation of the Teacher Behavior Checklist (TBC) for Brazilian students to evaluate their teachers (Study 1) and investigate its psychometric evidence (Study 2). In Study 1, evidence was favorable to the use of TBC for teacher evaluation by the student. In Study 2, 714 public university students participated (Average age $=24.3$ years; $S D=6.85$ ), $57.2 \%$ women. The TBC was applied collectively in the classroom. The results corroborated the two-factor model according to the instrument's original version, demonstrating an evidence of validity. Evidence of reliability has been documented (alpha $=0.92$; Test-Retest $=0.75$ ). This study presented an adequate instrument for the teacher formative evaluation and expanded Brazil's insertion in international research on effective teaching.
\end{abstract}

Keywords: teacher performance evaluation, higher education, psychometry

\section{Teacher Behavior Checklist: Evidências Psicométricas na Avaliação Docente por Estudantes Universitários Brasileiros}

\begin{abstract}
Resumo: Avaliações de desempenho auxiliam professores universitários a aperfeiçoar o ensino, especialmente quando baseadas em critérios internacionalmente reconhecidos. O objetivo deste estudo foi realizar uma adaptação transcultural do Teacher Behavior Checklist (TBC) para que discentes brasileiros avaliem seus professores (Estudo 1) e investigar suas evidências psicométricas (Estudo 2). No Estudo 1 as evidências foram favoráveis ao uso do TBC para a avaliação docente pelo discente. No Estudo 2, participaram 714 estudantes de universidade pública (Média de idade $=24,3$ anos; $D P=6,85$ ), 57,2\% mulheres. O TBC foi aplicado coletivamente em sala de aula. Os resultados corroboraram o modelo de dois fatores conforme a versão original do instrumento, demonstrando uma evidência de validade. Foram documentadas evidências de fidedignidade ( $\mathrm{alpha}=0,92$; Teste-Reteste $=0,75$ ). Este estudo apresentou instrumento adequado para a avaliação formativa docente e ampliou a inserção do Brasil na investigação internacional sobre ensino eficaz.
\end{abstract}

Palavras-chave: avaliação de desempenho do professor, ensino superior, psicometria

\section{Teacher Behavior Checklist: Evidencias Psicométricas en la Evaluación Docente por los Estudiantes Universitarios Brasileños}

\begin{abstract}
Resumen: Las evaluaciones de desempeño ayudan a que los docentes universitarios mejoren la enseñanza, sobre todo cuando se basan en criterios reconocidos internacionalmente. El presente estudio tuvo como objetivo llevar a cabo una adaptación transcultural de la Teacher Behavior Checklist (TBC) para que los estudiantes brasileños evalúen a sus profesores (Estudio 1), así como investigar las evidencias psicométricas (Estudio 2). En el Estudio 1, las evidencias fueron favorables al uso de la TBC para que el estudiante evalúe al profesor. En el Estudio 2, participaron 714 estudiantes de una universidad pública (Promedio de edad $=24,3$ años; $D E=6,85$ ), siendo el 57,2\% mujeres. La TBC se aplicó colectivamente en el aula. Los resultados corroboran el modelo de dos factores de acuerdo con la versión original del instrumento, lo que demuestra evidencia de validez. Se documentaron evidencias de fiabilidad (alfa $=0,92$; Test-Retest $=0,75)$. Este estudio presentó un instrumento adecuado para evaluar a los docentes y expandió la inserción de Brasil en la investigación internacional sobre la enseñanza efectiva.
\end{abstract}

Palabras clave: evaluación de desempeño docente, educación superior, psicometría

${ }^{1}$ Universidade Federal de Roraima, Boa Vista-RR, Brazil

${ }^{2}$ Universidade Federal de São Carlos, São Carlos-SP, Brazil

${ }^{3}$ Universidade Estadual de Londrina, Londrina-PR, Brazil

${ }^{4}$ Auburn University, Auburn-Alabama, USA

${ }^{5}$ Virginia Commonwealth University, Richmond-Virginia, USA

Article derived from the doctoral dissertation of the first author, under supervision of the second author, defended in 2017 in the Graduate Program in Psychology of Universidade Federal de São Carlos.

Correspondence address: Marcelo Henrique Oliveira Henklain. Universidade Federal de Roraima. Avenida Capitão Ene Garcês, 2412 - Aeroporto, Boa Vista-RR, Brazil. CEP 69.310-000. E-mail: marcelo.henklain@ufrr.br
One of the main social roles of the university professor is to teach (Twyman, 2014), whether in the classroom, research orientation, or internship supervision. Despite this, teaching at the Brazilian higher education level has been challenging due to factors such as: (a) university professors generally do not have planned and intentional training to teach (Oliveira \& Silva, 2012); (b) emphasis on academic production at the expense of teaching, at least, in public universities (Piolli, Silva, \& Heloani, 2015); or (c) in the case 
of these universities, there is a need to act simultaneously in teaching, research, extension and management activities, which can be complicated if there are not adequate working conditions (e.g., sufficient number of teachers, material resources). Given this paradox between the importance of teaching and the existing difficulties, the question is: How to favor teacher improvement concerning their performance in teaching?

An alternative is to use measurement instruments, with psychometric evidence, to assist in the evaluation of the teacher by the students. The result of this assessment is an opportunity for feedback (Mangiapanello \& Hemmes, 2015) to the teachers about their performance, which can help them to identify how to improve their teaching performance. The Teacher Behavior Checklist - TBC (Buskist, Sikorski, Buckley, \& Saville, 2002), whose name in English was maintained in Brazil because it is the international standard, has the advantage of being an internationally studied instrument that can assist in the formative assessment of university professors (Keeley, Smith, \& Buskist, 2006). This type of evaluation aims to benefit the professional development of the subject, not having the function of guiding administrative decisions as they occur in summative assessments (Cassettari, 2014).

The TBC consists of 28 items that describe teaching qualities and corresponding behaviors (Buskist et al., 2002). The student assesses how often the teacher shows these qualities. The higher the score, the more students considered that the teacher has qualities to favor a learning experience in which the study does not become aversive. The lower the score, the more the teachers need to consider changing their behavior about a given educational context. In this use of TBC, the behaviors indicate what students can evaluate about their teachers and what teachers can start doing if they do not receive a positive evaluation in specific item. It is a useful tool for Brazilian university professors.

The TBC was developed in the United States of America (USA), from the perspective of undergraduates, to help characterize an "effective teacher" (the authors of the TBC use expressions such as "expert or excellent teacher" - we adopt "effective teacher" as suggested by Henklain, Carmo, \& Haydu, 2018). Buskist et al. (2002) asked 114 undergraduates to list the teachers' qualities from whom they learned a lot and in a pleasant way. This procedure generated a list of 47 qualities, which was delivered to a second group of 184 undergraduate students whose task was to identify three behaviors related to each of these qualities. Three researchers organized the results in a list of 28 qualities and their respective behavioral examples.

This list was delivered to 916 undergraduate students and 118 teachers, who were asked to select the top 10 qualities. Participants agreed on six qualities, differing only in the order of importance: teachers favored technical-pedagogical behaviors (e.g., effective communication), while students prioritized friendly and reliable teacher-student interaction (Buskist et al., 2002). The results were positive, and the study was innovative because few known instruments had the checklist format and items elaborated from the perspective of undergraduate students on teaching excellence (a formal theoretical model was not adopted to define the "effective teacher" construct).

Then, many studies emerged, mainly intending to replicate the work of Buskist et al. (2002) with other university samples/cultures and to investigate the relevance of the TBC qualities so that the teacher is considered effective. For example, Ismail and Groccia (2017) compared the results of selecting the 10 most important items from the perspective of 448 teachers (309 trained in the USA and 139 in other countries, mainly European and Asian), with convergence on 8 out of 10 qualities.

Another important step was taken by Keeley et al. (2006), who adapted the checklist to the format of an instrument with 28 items to measure, according to the student perspective, the performance of the university professor based on a five-point Likert frequency scale ranging from " $1=$ never presents" the " $5=$ always presents". The researchers conducted two studies to investigate the psychometric properties of this TBC version.

In Study 1, 313 students evaluated four teachers at the end of the semester. Exploratory Factor Analysis was performed by extraction by maximum likelihood, non-orthogonal oblimin rotation, with acceptance of factors whose eigenvalue was greater than one and items with a factorial load above 0.30 . Two factors were identified, "Careful and Supportive" (13 items) and "Professional Competence and Communication Skills" (11 items), whose correlation was 0.73 , explaining $53 \%$ of the variance. Four items $(5,9,16$, and 17) were not classified into either of the two factors, but were not excluded from the scale, as they had evidence of content validity from other studies. Cronbach's alpha of the first subscale was 0.93 , that of the second was 0.90 , and that of the total TBC was 0.95 (Keeley et al., 2006).

In Study 2, conducted by Keeley et al. (2006), another 313 students evaluated five teachers in the middle of the semester, and 322 repeated the evaluation at the end of the semester. The Test-Retest generated a positive result $(r=0.71 ; p<0.01)$. A Confirmatory Factor Analysis was also conducted with four indexes ( $x^{2}, \mathrm{NFI}, \mathrm{CFI}$, and RMSEA) to assess the degree of adjustment of three factorial solutions, among them the two-factor model of Study 1. The results showed that one- and two-factor solutions produced adequate indices with an advantage for the two-factor model, which was preferred for theoretical reasons since several studies (e.g., Buskist et al., 2002; Richmond, Boysen, Gurung, Tazeau, Meyers, \& Sciutto, 2014) suggest that teacher evaluation can be summarized in two dimensions: technical-pedagogical and relational.

Landrum and Stowell (2013) showed, then, that students recognize when a teacher has a quality indicated by the TBC items. They selected eight TBC qualities, recorded teacher classes, and separated excerpts that presented one or more qualities. The participants, who did not know the videotaped teachers, watched the videos and, based on a list of the eight 
qualities and their definitions, assessed whether the teachers had any of them and when each one appeared on the video. The researchers obtained significant correlations, ranging from 0.50 (moderate) to 0.71 (strong), between identified qualities and video excerpts.

Other studies (Lammers, Savina, Skotko, \& Churlyaeva, 2010; Ripoll-Núñez, Mojica-Ospina, Torres-Riveros, \& Castellanos-Tous, 2018) investigated whether the importance attached to TBC items for effective teaching was restricted to the American university culture. Lammers et al. (2010) assessed the degree of importance of each TBC item for a teacher to be considered effective, on a scale ranging from " $1=$ somehow important" to " 7 = extremely important". One hundred eighteen (118) teachers and 179 American students, 45 teachers, and 222 Russian students participated. In 21 of the 28 items, no differences were found in the participants' responses, and these responses indicated that the TBC items were important. Differences occurred in Items 1, 2, 16, 17, 18, 23, and 25. Ripoll-Núñez et al. (2018), in turn, asked 120 teachers and 1199 Colombian university students from different courses to evaluate how often effective teachers presented the qualities of TBC, according to a five-point scale: " 1 = never presents" to "5 = always presents". Colombians rated all the qualities of TBC as frequent for the effective teacher (for students, the averages were greater than 3.7 and for teachers greater than 4.1), suggesting that despite cultural differences the teaching practices present in the TBC are internationally recognized as relevant.

In summary, the psychometric evidence obtained justifies the realization of new studies with TBC and its application in the formative assessment of university professors. However, before one can use the TBC in Brazil, it is necessary to investigate the extent to which psychometric evidence supports that TBC is useful and appropriate to assist in the formative assessment of Brazilian university professors. This study aimed to carry out a cross-cultural adaptation of the Teacher Behavior Checklist (TBC) for Brazilian students to evaluate their teachers (Study 1) and investigate its psychometric evidence (Study 2).

Study 1. The objective was to develop a crosscultural adaptation of the TBC for teacher evaluation by Brazilian undergraduate students, based on the study by Keeley et al. (2006). The guidelines of Borsa, Damásio, and Bandeira (2012), and Andrade and Valentini (2018) were followed. The research was initiated only after the approval of the TBC authors.

Initially, two Brazilian translators, both with experience in psychology and in the English, carried out independent translations of the TBC from which the synthesis version was prepared by the first author of this study. This version was evaluated by a committee composed of three Brazilian researchers: two PhDs with experience in psychometry and higher education ( $\mathrm{J} 1$ and J2) and a doctoral student in Psychology (J3), who was studying the evaluation of teaching performance. Each judge received a file in Excel $2010^{\circledR}$ with (a) instructions on how to evaluate the synthesis version, (b) summary of the TBC psychometric evidence, (c) spaces for assessing the level of clarity of instructions and clarity, practical pertinence and theoretical relevance of items of the scale: "1 = very little" to "5 = very much", and (d) spaces for classification of the items in one of two factors: "Careful and Supportive" and "Professional Competence and Communication Skills".

The evaluations were analyzed qualitatively and quantitatively by calculating the Content Validity Coefficient (CVC) for each item and the whole scale. The Kappa Coefficient was also calculated to assess the agreement between the judges in the classification of $\mathrm{TBC}$ items. Items whose average CVC in clarity, practical pertinence, and theoretical relevance was greater than 0.80 and Kappa coefficients greater than or equal to 0.60 were considered adequate.

The CVCs of most items in the three dimensions were adequate $(>0.80)$. Only Item 17 , in the relevance dimension $(\mathrm{CVC}=0.70)$, was below the criterion. The judges questioned the relevance of this item that relates the teacher's way of dressing with the quality of teaching. Despite this, Item 17 was maintained due to the favorable evidence it has from other studies. A precaution adopted was to name this quality as "professional presentation/formal posture" instead of "professionalism" (initial translation). The total CVC of the items was equal to 0.95 (evidence of content validity). The Kappa coefficient between $\mathrm{J} 1$ and $\mathrm{J} 2 / \mathrm{J} 2$ and $\mathrm{J} 3$ was 0.5 (limit) and between $\mathrm{J} 1$ and $\mathrm{J} 3$ was 1.0 (perfect). The coefficient of 0.5 was accepted because it was only missing one agreement between the judges for the criterion to be reached, and J2 was unable to classify Item 17 because she did not associate it with any of the two factors. Despite the aspects that can be improved, the judges considered the TBC version suitable for use and that its items are relevant to measure the performance of the university professor (evidence of content validity).

Then, a face-to-face meeting was held with a committee of members of the target population composed of four Psychology students (one was a former Electrical Engineering student) and one of Computer Science, three men and two women. All were students at a public university. Participants were asked to complete the TBC thinking of an undergraduate teacher. Then they evaluated the TBC instructions and each item to indicate whether they were clear (the same scale used by the judges). For what was not clear, the participant should indicate what to improve. All items showed good CVC results (above 0.80), and participants praised the instrument for its clarity and ease of completion (evidence of semantic validity).

Then a pilot study was carried out with 65 participants, 47 women, 17 men and one did not inform his or her gender; $90.77 \%$ had incomplete higher education, $6.15 \%$ completed higher education and $3.08 \%$ incomplete specialization; 45 were students from public universities and 20 from private universities; 23 were graduate students 
in Administration, 20 in Psychology, 11 in Dentistry, five in Biological Sciences, two in Civil Engineering, two in Physics, one in Electrical Engineering and one in Mathematics; with a mean age of 22.45 years $(S D=3.93$; two participants did not inform their age). Participants were advised that they would act as TBC judges. They should think of a teacher they had in college and evaluate them based on the TBC. Then, they should judge whether the item was evident and answer it in a dichotomous scale: "yes" or "no" and, if it was not, they had to explain why by writing. Respondents tended to positively evaluate their teachers or choose good teachers to evaluate (most responses were 4 and 5, 1333 selections, compared to 190 selections from points 1 and 2 of the scale). Regarding the clearness of items, an average of $97.42 \%$ "yes" responses (evidence of semantic validity) was obtained.

A Portuguese language teacher subsequently conducted a grammatical analysis of the instrument. She pointed out seven changes related to the replacement or suppression of words, punctuation, and spelling. Finally, the TBC in the adapted version was handed over to a Psychology researcher, English language native, for the reverse translation to be done. This TBC version was sent to one of the instrument authors. He then attested to the quality of the adaptation and authorized its use in Brazil.

Study 2. This study aimed to investigate preliminary evidence of the validity of the internal structure and other variables (level of learning and items on a scale unrelated to teacher evaluation) and the reliability of the TBC adapted version.

\section{Method}

\section{Participants}

Seven hundred and fourteen students from a public university in Roraima, 410 women and 304 men, with an average age of 24.27 years $(S D=6.85) ; 517$ declared to belong to the middle class, 176 to the lower class, 13 to the upper class and eight did not answer; 656 had incomplete higher education, 40 completed higher education, 10 were taking specialization courses, and eight had complete specialization courses. The distribution per course was as follows: Psychology, 85; Civil Engineering, 75; Pedagogy, 55; Business, 49; Biology, 47; Accounting, 46; Economy, 40; Zootechnics, 40; Electrical Engineering, 38; Architecture, 31; Executive Secretariat, 28; History, 25; Law, 24; Computer Science, 19; Chemistry, 19; Journalism, 18; Languages, 17; Visual Arts, 16; Geography, 11; Agronomy, nine; Geology, nine; Music, eight; Mathematics, two; Physics, two; International Relations, one. At the time of collection, the university had 7853 undergraduate students, according to the Department of Academic Registration and Control. This sample represented $9.10 \%$ of that population.
A total of 229 students took part in the retest, $62.88 \%$ women, with a mean age of 23.70 years $(S D=6.59)$.

\section{Instruments}

The protocol, identified by a code, was composed of: (a) $T B C$ adapted to Portuguese (which included instructions to participants, the 28 items that make up the instrument and the five-point frequency scale, ranging from " $1=$ never presents the quality "to" 5 = always presents"; according to the Appendix), accompanied by an item created for this study whose function was to allow students to self-assess how much they learned from the teacher: "1 = very low" to "5 = very high"; (b) Academic Experience Satisfaction Scale (ESEA, 35 items with a five-point satisfaction scale, " $1=$ not at all satisfied" to "5 = totally satisfied", three factors, Course Satisfaction, Development Opportunity, and Satisfaction with the Institution, alpha $=0.94$; Schleich, Polydoro, \& Santos, 2006); and (c) Student Characterization Questionnaire, which requested information such as age, sex, education, and social class.

\section{Procedure}

Data collection. The first author of this study contacted teachers by email or phone, explained the research objectives, and requested 40 to 60 minutes of class. It was explained that accepting to participate meant that the teacher agreed to be evaluated by the students without having access to the evaluation data, as requested by the Ethics Committee to prevent some teachers from punishing the students' behavior depending on the evaluation results. The sample was defined by convenience.

For teachers who agreed to participate, a day and time was scheduled. As agreed, upon arriving at the classroom, the applicator asked the teacher to leave the room as agreed and then explained the research objectives to the students. Then, the applicator distributed the Informed Consent Terms (ICFs) and explained that the teacher would not have access to the assessment results, that participation was free and that anyone who agreed to participate should sign the ICF and call the person responsible for the collection to receive a research protocol. Each participant was asked to keep their protocol code to facilitate the TBC reapplication. The main instruction provided was as follows: "Please rate the Professor indicated by the researcher to the extent that you believe that the Professor has such qualities and presents some of the exemplary behaviors". The ESEA would be applied only when the researcher was authorized to use 60 minutes of the class time.

In reapplication, after scheduling with the teacher, the applicator arrived in the classroom and explained the reason for the new collection, clarifying that participation was voluntary. Participants who had their protocol codes were asked to inform them and everyone who agreed to participate had to fill in some personal data again, so that their first 
protocols could be found even if they did not remember the code. This second collection started after the 30-day break and, due to difficulties in finding the students in their new classes, it lasted 53 days.

Data analysis. The software used was R Studio based on R version 3.4.1 (R Core Team, 2017) and Factor Analysis version 10.5.03 (Lorenzo-Seva \& Ferrando, 2017). It was verified, with the Shapiro-Wilk test $(=5 \%)$, that there was no normal data distribution (all items presented significant results, $p$-value $<0.05$ ). Considering this reason and the fact that was adopted an ordinal frequency scale in the TBC, non-parametric statistics for the data analysis.

Three validity pieces of evidence were analyzed: Validity based on external criteria, calculated by the correlation between the TBC score and the student's self-assessment on their learning level. It was expected to obtain a positive and statistically significant correlation; Divergent validity, calculated by the correlation between TBC and the score in 15 items of ESEA whose content has no relation to the evaluation of teachers (e.g., "29. Services offered by the library"; selected items: $4,5,6,7,15,16,18$, $19,20,22,23,27,29,30,32)$. No correlation was expected to be found; and Validity of the internal structure, calculated via Exploratory Factor Analysis (EFA). EFA involved the steps described as follows.

The factorability of the data matrix was assessed by two tests: Bartlett's Sphericity, with the p-value $<0.05$ being the expected result; and KMO, with values greater than 0.80 being considered adequate. Subsequently, the decision on the number of factors to retain was based on the Parallel Analysis (PA) proposed by Timmerman and Lorenzo-Seva (2011). In this case, the comparison between real and randomly generated data is based on the common variance obtained by the Minimum Rank Factor Analysis (MRFA). The Unweighted Least Squares (ULS) method was used to extract the factors. This method was suggested by Lee, Zhang, and Edwards (2012) as an adequate and practical alternative for performing EFA with ordinal data. The rotation method chosen was oblique of the direct oblimin type (Damásio, 2012). When using this rotation, Hair, Black, Babin, Anderson, and Tatham (1995/2009) suggested analyzing the factorial pattern matrix. Only factorial loads greater than or equal to 0.30 were accepted (according to Hair et al., 1995/2009). In cases of cross-load, the variable was allocated to the factor with the highest load, when the difference was greater than 0.20 , and, in other cases, it was allocated to a factor whose meaning was similar to that of the TBC original version to prioritize the maintenance of the characteristics of the original instrument and some initial possibility of data comparison.

Evidence of reliability was investigated using Cronbach's alpha, Mcdonald's Omega (expected result: 0.80) and Test-Retest (expected result: positive correlation 0.60). Two one-tailed Spearman correlations were calculated in the Test-Retest: based on the total score on the TBC and the scores of the factors found in the EFA.

\section{Ethical Considerations}

This study was approved by the Human Research Ethics Committee of the Universidade Federal de Roraima, CAAE 54448416.6.0000.5302 (Opinion 1,476,568).

\section{Results}

The result of the KMO test was 0.93 and the sphericity test showed a $p$-value $<0.001$. The results were adequate in both tests, enabling the conduct of EFA. In the PA, only the percentages of variance in the real data of the first two factors (42.60 and 10.80) exceeded the percentages of variance in the random average data (7.10 and 6.70) and the 95 percentile (7.80 and 7.30). Therefore, only the first two factors met the retention criteria proposed by Timmerman and Lorenzo-Seva (2011). This two-factor model has an explained variance of $48.88 \%$, in addition to being similar to the one proposed by Keeley et al. (2006). Table 1 shows the factorial structure of the TBC in the original and adapted versions (the wording of the items was summarized to favor the data visualization. Correctly worded items are available in the Appendix).

Based on the EFA results (Table 1), and the data analysis procedures, Items $1,2,7,10,11,12,13,17,22,23,24$, and 28 were included in Factor 1. In Factor 2, Items 3, 4, 5, 6, 8, $9,14,15,16,18,19,20,21,25,26$, and 27 were included. Factor 1 was named Relational Behaviors (RB), and Factor 2 was Pedagogical Behaviors (PB), based on the proposal by Henklain et al. (2018). These factors showed positive correlations and with moderate magnitude $\left(r_{\mathrm{s}}=0.59, p<0.01\right.$, $N=714, R^{2}=0.36$ ). It was found 14 matches (in 28 items) between the items that make up Factors 1 and 2 in this research and the factorial structure proposed by Keeley et al. (2006).

A positive and moderate correlation was obtained between the TBC score and the students' self-assessment on the level of learning $\left(r_{\mathrm{s}}=0.40, p<0.01, N=714\right)$. Positive correlations were found, ranging from low to moderate, between Factor 1 (RB) and the level of learning $\left(r_{\mathrm{s}}=0.28, p<0.01, N=714\right)$ and between Factor $2(\mathrm{~PB})$ and the level of learning $\left(r_{\mathrm{s}}=0.39, p<0.01, N=714\right)$. The correlation between the TBC score and the 15 ESEA items met expectations because it was weak $\left(r_{\mathrm{s}}=0.223\right.$, $p<0.01, N=270 ; \mathrm{R}^{2}=4.97 \%$ ).

The Cronbach alpha of the global scale was 0.92 (excellent) and the Omega, 0.94. The alpha value of the Relational Behaviors subscale was $0.85($ Omega $=0.89)$ and the Pedagogical Behaviors subscale was $0.90($ Omega $=0.92)$, both adequate. Removing items did not substantially alter the alpha.

The Test-Retest correlation was positive, strong and statistically significant $\left(r_{\mathrm{s}}=0.748, p\right.$ (one-tailed $)<0.01$, $N=229$ ). The determination coefficient indicated that $56 \%$ of the variation in the retest was associated with the test. Regarding Factors 1 and 2, the Test-Retest correlations were statistically significant, ranging from moderate to strong (Factor 1: $r_{\mathrm{s}}=0.59, p$ (one-tailed) $<0.01, N=229$; Factor 2: $r_{\mathrm{s}}=0.75, p($ one-tailed $\left.)<0.01, N=229\right)$. 
Table 1

Exploratory Factor Analysis of the original and adapted versions of the Teacher Behavior Checklist

\begin{tabular}{|c|c|c|c|c|c|}
\hline \multirow{2}{*}{ TBC Items } & \multicolumn{2}{|c|}{ Original TBC version } & \multicolumn{3}{|c|}{ Adapted TBC version } \\
\hline & Caring & Competent & $\mathrm{RB}$ & PB & $h^{2}$ \\
\hline 1. Accessible/available & 0.58 & & 0.33 & & 0.3 \\
\hline 2. Attentive/friendly & 0.34 & 0.44 & 0.67 & & 0.5 \\
\hline 3. Exercises authority & & 0.63 & -0.35 & 0.74 & 0.4 \\
\hline 4. Confident & & 0.85 & & 0.74 & 0.6 \\
\hline 5. Creative and interesting & 0.34 & 0.39 & & 0.75 & 0.5 \\
\hline 6. Effective communicator & & 0.71 & & 0.74 & 0.6 \\
\hline 7. Concerned about students & 0.79 & & 0.54 & & 0.4 \\
\hline 8. Enthusiastic & 0.52 & & & 0.62 & 0.6 \\
\hline 9. Sets goals & 0.37 & 0.3 & & 0.57 & 0.4 \\
\hline 10. Flexible/open to change & 0.65 & & 0.52 & & 0.4 \\
\hline 11. Good listener & 0.39 & 0.4 & 0.47 & & 0.4 \\
\hline 12. Joyful/positive attitude & & 0.53 & 0.47 & & 0.4 \\
\hline 13. Humble & 0.55 & 0.3 & 0.73 & & 0.5 \\
\hline 14. Masters the topic taught & & 0.71 & & 0.7 & 0.5 \\
\hline 15. Prepared & & 0.46 & & 0.6 & 0.5 \\
\hline 16. Displays current information & 0.38 & & & 0.7 & 0.5 \\
\hline 17. Professional Presentation & 0.38 & 0.33 & 0.38 & & 0.2 \\
\hline 18. Promotes discussions & 0.65 & & & 0.65 & 0.4 \\
\hline 19. Promotes critical thinking & 0.55 & & & 0.71 & 0.5 \\
\hline 20. Provides constructive feedback & 0.84 & & & 0.52 & 0.4 \\
\hline 21. Punctual & & 0.4 & & 0.53 & 0.4 \\
\hline 22. Establishes link & 0.81 & & 0.44 & 0.36 & 0.5 \\
\hline 23. Realistic expectations & 0.62 & & 0.40 & 0.37 & 0.4 \\
\hline 24. Respectful & 0.39 & 0.43 & 0.84 & & 0.6 \\
\hline 25. Sensitive and persistent & 0.81 & & 0.35 & 0.5 & 0.5 \\
\hline 26. Seeks to improve & 0.9 & & & 0.7 & 0.5 \\
\hline 27. Technologically competent & & 0.48 & & 0.5 & 0.3 \\
\hline 28. Understanding & 0.64 & & 0.72 & & 0.5 \\
\hline Total of items & 13 & 11 & 12 & 16 & --- \\
\hline
\end{tabular}

Note. $\mathrm{RB}=$ Relational Behaviors; $\mathrm{PB}=$ Pedagogical Behaviors.

\section{Discussion}

The results of Study 1 indicated that the present version of the TBC meets the necessary requirements for use in research and, in Study 2, the results of the EFA showed that the TBC items have correlations with each other, which can be summarized in a two-factor structure, and that this structure is similar to that identified in the original version of the TBC (Keeley et al., 2006). These results are evidence of validity and reliability which encourages the conduct of new research with $\mathrm{TBC}$ in the Brazilian university culture. There is the possibility of comparing the results of researches carried out in the USA and Brazil, which can assist in the identification of practices that are globally useful for teaching - even though an adequate comparison requires evidence of measurement invariance. The results corroborated other studies that showed the relevance of
$\mathrm{TBC}$ and the feasibility of using it in the formative assessment of teachers (Keeley et al., 2010; Landrum \& Stowell, 2013).

The fact that the correspondence was not total or greater between the original version and this adaptation demonstrates that the same item can be perceived and interpreted in different ways depending on the person and their cultural context, or that TBC items involve, simultaneously, pedagogical and relational dimensions. For example, the inclusion of Items 8, "Enthusiastic", and 25, "Sensitive and Persistent", in Factor 2 may surprise. However, this is explained because in Item 8 the behaviors reflect the teacher's actions to create motivational conditions conducive to learning. Item 25 describes behaviors of monitoring student learning and acting on their needs to ensure that everyone learns. Both cases deal with aspects of teacher-student interaction, but emphasize the promotion of learning (pedagogical dimension). For this reason, Item 
25 was allocated to Factor 2, despite the cross-load. In fact, the correlation found between the factors also allows us to interpret that they do not assess totally independent aspects. This result was expected, after all it is difficult to separate, except for didactic reasons (or to emphasize some aspect of performance), the teaching performance in an exclusively pedagogical or relational dimension (Henklain et al., 2018).

Despite some items performed below the defined criteria, for now it was decided that none should be excluded just as Keeley et al. (2006) to facilitate comparisons between the different versions of the TBC and because it is a first exploratory study in only one Brazilian university. For future studies, it is important to consider that Item 17 presented low factor load and commonality, in addition to its issues raised in Study 1; Item 3 presented a cross-load, but with a difference of 0.39 between the factors; Items 22 and 23 also showed a cross-load and the factor in which they were allocated was the same as in the original version of the TBC (that is, the choice was theoretical and pragmatic).

Evidence of validity based on external criteria was obtained by the correlation between the TBC score, and the level of learning reported by the students. However, the magnitude of the correlations was moderate. This was because other variables, in addition to the teacher, are associated with learning, such as the student's study routine. It was also found that the correlation between the TBC score and the 15 ESEA items was positive, although of low magnitude. This also suggests that other variables can affect teacher assessment, even if they are not directly related to the teacher's behavior. There may be an indirect relationship because variables like the absence of audiovisual resources can negatively impact the assessment of teaching competence on the use of technologies. Therefore, it is recommended to avoid making administrative decisions about the teacher's career solely on the basis of student assessment, most suitable for formative assessment (Uttl, White, \& Gonzalez, 2017). This correlation confirmed the prediction that the TBC items and the 15 items of the ESEA measure different constructs (divergent validity), as only $4.97 \%$ of the variability in the TBC scores was associated with the score in the 15 items of the ESEA that were not directly related with teachers or teaching.

The Cronbach's alpha, McDonald's Omega and TestRetest data indicated that the TBC in the Portuguese adapted version is reliable for assessing teacher performance, that is, although student assessments are influenced by many variables, their main aspects do not change, for example, only by the passage of time. In this study, the first assessment was carried out at the semester-end and the reevaluation after recess, a period without contact with teachers that could justify changes in the assessments.

These results suggest that $\mathrm{TBC}$ is a promising tool to assist in the formative assessment of university professors. It is known that the use of teacher evaluation by students is controversial. However, when considering some precautions (e.g., conducting assessments before exam periods), it consists of a particular source of low-cost information (and an opportunity for feedback) on teacher performance (Richmond et al., 2014).
At the moment, it is expected that student feedback from the TBC and the behavioral indications of this instrument will be useful for teachers to identify how to improve their professional performance. It is also expected that the achievement of what is foreseen in the TBC by the teacher will act as a reinforcer for their teaching behavior. Indeed, other conditions, in addition to TBC, will be necessary, especially to develop complex behaviors. Therefore, the development of instruments must be accompanied by research on teacher education and the teacher cannot be seen as solely responsible for learning (university and students need to contribute).

Although there are no standardization studies, this does not prevent the use of TBC in applied contexts. An analysis of each item and/or the total score (calculated by the sum or average of the items) can be carried out, always avoiding decontextualized interpretations of historical, social, personal, and teaching environment conditions.

Three main limitations of this study were identified: (a) the procedure of indicating a teacher to be evaluated reduced the variability of the data (one solution would be asking for each participant to evaluate a teacher with whom he or she is attending classes at the time of data collection); (b) future studies should increase the number of reapplications of TBC and carry them out in the same period to reduce the effect of intervening variables on the student evaluation; (c) the sample was defined by convenience at only one university, which makes it difficult to generalize results. Besides these caveats, future studies should investigate the convergent validity of $\mathrm{TBC}$ and carry out measurement invariance analyses to investigate the compatibility between the original and adapted versions of TBC.

Finally, it is important to stress that the TBC presented a two-factor structure comparable to the original version and to what the literature foresees as relevant in the teacher evaluation. It was also found that the TBC items favor verbal responses from Brazilian students under control of the teacher's observed behaviors in the classroom and not just from intervening variables, and that these responses remain similar over time. Thus, TBC can be a useful tool for providing feedback to teachers which could help them to improve teaching.

\section{References}

Andrade, J. M. de, \& Valentini, F. (2018). Diretrizes para a construção de testes psicológicos: A Resolução CFP $\mathrm{n}^{\circ}$ 009/2018 em destaque [Guidelines for the Construction of Psychological Tests: Regulation CFP No: 009/2018 in Highlight]. Psicologia: Ciência e Profissão, 38 (número especial), 28-39. doi: 10.1590/1982-3703000208890

Borsa, J. C., Damásio, B. F., \& Bandeira, D. R. (2012). Adaptação e validação de instrumentos psicológicos entre culturas: algumas considerações [Cross-cultural adaptation and validation of psychological instruments: some considerations]. Paidéia, 22(53), 423-432. doi: 10.1590/S0103-863X2012000300014 
Buskist, W., Sikorski, J., Buckley, T., \& Saville, B. K. (2002). Elements of master teaching. In S. F. Davis \& W. Buskist (Eds.), The teaching of psychology: Essays in honor of Wilbert J. McKeachie and Charles L. Brewer (pp. 27-40). New York, NY: Psychology Press.

Cassettari, N. (2014). Avaliação de professores: Uma questão de escolhas [Teacher evaluation: A matter of choice]. Estudos em Avaliação Educacional, 25(57), 166-197. doi:10.18222/eae255720142829

Damásio, B. F. (2012). Uso da análise fatorial exploratória em psicologia [Uses of exploratory factorial analysis in psychology]. Avaliação Psicológica, 11(2), 213-228. Retrieved from https://bit.ly/2M6PSUR

Hair, J. F., Jr., Black, W. C., Babin, B. J., Anderson, R. E., \& Tatham, R. L. (2009). Análise multivariada de dados [Multivariate data analysis] (A. S. Sant'Anna, Trans., 6th ed.). Porto Alegre, RS: Bookman. (Original work published 1995).

Henklain, M. H., Carmo, J. S., \& Haydu, V. B. (2018). Contribuições analítico-comportamentais para descrever o repertório de professores universitários eficazes [Behavior-analytical contributions to describe the repertoire of effective university teachers]. Revista Brasileira de Orientação Profissional, 19(2), 197-207. doi:1026707/1984-7270/2019v19n2p197

Ismail, E. A., \& Groccia, J. E. (2017). Foreign and U.S-educated faculty members' views on what constitutes excellent teaching: Effects of gender and discipline. To Improve the Academy, 36(1), 20-38. doi:10.1002/tia2.20056

Keeley, J. W., Smith, D., \& Buskist, W. (2006). The Teacher Behaviors Checklist: Factor Analysis of its utility for evaluating teaching. Teaching of Psychology, 33(2), 84-91. doi:10.1207/s15328023top3302_1

Lammers, W. J., Savina, E., Skotko, D., \& Churlyaeva, M. (2010). Faculty and student perceptions of outstanding university teachers in the USA and Russia. Educational Psychology: An International Journal of Experimental Educational Psychology, 30(7), 803-815. doi:10.1080/ 01443410.2010 .512382

Landrum, E. R., \& Stowell, J. R. (2013). The reliability of student ratings of master teacher behaviors. Teaching of Psychology, 40(4), 300-303. doi:10.1177/0098628313501043

Lee, C. T., Zhang, G., \& Edwards, M. C. (2012). Ordinary least squares estimation of parameters in exploratory Factor Analysis with ordinal data. Multivariate Behavioral Research, 47(2), 314-339. doi:10.1080/0027 3171.2012.658340
Lorenzo-Seva, U., \& Ferrando, P. J. (2017). Factor Analysis (10.5.03). Retrieved from https://bit.ly/2TvCMnR

Mangiapanello, K. A., \& Hemmes, N. S. (2015). An analysis of feedback from a behavior analytic perspective. The Behavior Analyst, 38(1), 51-75. doi:10.1007/s40614014-0026-x

Oliveira, V. S., \& Silva, R. F. (2012). Ser bacharel e professor: Dilemas na formação de docentes para a educação profissional e ensino superior [Professors with bachelor's degrees: Problems in education teacher training and higher education]. Holos, 28(2), 193-205. doi:10.15628/ holos.2012.913

Piolli, E., Silva, E. P., \& Heloani, J. R. M. (2015). Plano Nacional de Educação, autonomia controlada e adoecimento do professor [National Education Plan, controlled autonomy and teacher illness]. Cadernos Cedes, 35(97), 589-607. doi:10.1590/CC0101-32622015154849

R Core Team. (2017). R: A language and environment for statistical computing. Vienna, Austria: R Foundation. Retrieved from https://www.R-project.org/

Richmond, A. S., Boysen, G. A., Gurung, R. A. R., Tazeau, Y. N., Meyers, S. A., \& Sciutto, M. J. (2014). Aspirational model teaching criteria for psychology. Teaching of Psychology, 41(4), 281-295. doi:10.1177/0098628314549699

Ripoll-Núñez, K., Mojica-Ospina, I. E., Torres-Riveros, A. C., \& Castellanos-Tous, M. S. (2018). Teacher's and student's perceptions of excellence in teaching in Colombia. New Directions for Teaching and Learning, 156, 57-65. doi: 10.1002/t1.20317

Schleich, A. L. R., Polydoro, S. A. J., \& Santos, A. A. A. (2006). Escala de satisfação com a experiência acadêmica de estudantes do ensino superior [Scale of satisfaction with academic experience of students of higher education]. Avaliação Psicológica, 5(1), 11-20. Retrieved from https://bit.ly/2Zx2eNC

Timmerman, M. E., \& Lorenzo-Seva, U. (2011). Dimensionality assessment of ordered polytomous items with parallel analysis. Psychological Methods, 16(2), 209-220. doi:10.1037/a0023353

Twyman, J. S. (2014). Envisioning education 3.0: The fusion of behavior analysis, learning science and technology. Revista Mexicana de Análisis de la Conducta, 40(2), 20-38. doi: 10.5514/rmac.v40.i2.63663

Uttl, B., White, C. A., \& Gonzalez, D. W. (2017). Metaanalysis of faculty's teaching effectiveness: Student evaluation of teaching ratings and student learning are not related. Studies in Educational Evaluation, 54, 22-42. doi:10.1016/j.stueduc.2016.08.007 
Marcelo Henrique Oliveira Henklain is a Ph.D Professor of the Universidade Federal de Roraima, Boa Vista-RR, Brazil.

João dos Santos Carmo is a Ph.D Professor of the Universidade Federal de São Carlos, São Carlos-SP, Brazil.

Verônica Bender Haydu is a Ph.D Professor of the Universidade Estadual de Londrina, Londrina-PR, Brazil.

Monalisa Muniz is a Ph.D Professor of the Universidade Federal de São Carlos, São Carlos-SP, Brazil.

William Buskist is a Ph.D Professor of the Auburn University, Auburn-Alabama, USA.

Jared Wayne Keeley is a Ph.D Professor of the Virginia Commonwealth University, Richmond-Virginia, USA.

Authors' contributions:

The authors Marcelo Henrique Oliveira Henklain and Monalisa Muniz made substantial contributions to the conception and design of this study, to the analysis and interpretation of data and to the review and approval of the manuscript of the final version. The authors João dos Santos Carmo and Verônica Bender Haydu made substantial contributions to the conception and design of this study and to the review and approval of the final version manuscript. Authors William Buskist and Jared W. Keeley made substantial contributions to the review and approval of the final version manuscript. All authors assume public responsibility for the manuscript content.

Received: Jun. 18, 2018

1st Revision: Jan. 10, 2019

2nd Revision: May. 21, 2019

Approved: Jun. 11, 2019

How to cite this article:

Henklain, M. H. O., Carmo, J. S., Haydu, V. B., Muniz, M., Buskist, W., \& Keeley, J. W. (2020). Teacher behavior checklist: Psychometric evidence in teacher evaluation by Brazilian university students. Paidéia (Ribeirão Preto), 30, e3025.doi:https://doi.org/10.1590/1982-4327e3025 


\title{
Apêndice
}

\author{
Teacher Behavior Checklist (TBC) - Versão Brasileira
}

Instruções: na tabela abaixo estão descritas 28 qualidades de um(a) Professor(a) e os comportamentos que as exemplificam (qualidades estão em negrito e comportamentos entre parênteses). Por favor, avalie o(a) Professor(a) na medida em que você acredita que esse(a) Professor(a) possui tais qualidades e apresenta alguns dos comportamentos exemplificativos, ou seja, você pode considerar que o(a) Professor(a) possui determinada qualidade ainda que não apresente todos os comportamentos colocados entre parênteses. Para cada um dos 28 itens, utilize a escala abaixo para a sua avaliação e, na coluna de respostas, coloque um X sobre o número que melhor representa a sua forma de pensar. Não existem respostas certas ou erradas.

$\mathbf{1}=$ Nunca apresenta(ou) comportamentos que exemplificam esta qualidade.

$\mathbf{2}=$ Raramente apresenta(ou) comportamentos que exemplificam esta qualidade.

3 = Às vezes apresenta(ou) comportamentos que exemplificam esta qualidade.

$4=$ Frequentemente apresenta(ou) comportamentos que exemplificam esta qualidade.

$5=$ Sempre apresenta(ou) comportamentos que exemplificam esta qualidade.

\section{Qualidades do(a) Professor(a) (comportamentos exemplificativos)}

Respostas

01. Acessível/disponível (Informa horário de trabalho; disponibiliza horário para atender os alunos; disponibiliza seu contato telefônico, de WhatsApp e de e-mail; responde ao contato dos alunos).

02. Atencioso(a)/amigável (Sorri; cumprimenta os alunos; inicia conversas; abre espaço para perguntas; responde respeitosamente aos comentários dos alunos).

03. Exerce autoridade (Estabelece regras claras para a disciplina; mantém a ordem em sala de aula; fala de modo firme, em tom de voz alto e forte).

04. Confiante (Fala de modo claro; apresenta argumentos para justificar as suas convicções; mantém contato visual; responde às perguntas corretamente).

05. Criativo(a) e interessante (Experimenta diferentes métodos de ensino; utiliza recursos tecnológicos para apoiar e enriquecer suas aulas; utiliza exemplos interessantes, relevantes e pessoais; não é monótono(a); desenvolve atividades práticas em sala de aula).

06. Comunicador(a) eficaz (Fala claramente e de modo que todos consigam ouvir e compreender; utiliza a língua portuguesa corretamente; fornece exemplos claros e convincentes).

07. Encoraja e demonstra preocupação com os alunos (Elogia o bom trabalho dos alunos; ajuda quando os alunos necessitam; atribui pontos extras em função do desempenho dos alunos; sabe os nomes dos alunos).

08. Entusiasmado(a) pelo ensino e pelo tema que ensina (Sorri durante a aula; prepara atividades de sala de aula interessantes; utiliza gestos e expressa emoções para enfatizar pontos importantes; não se atrasa para a aula).

09. Estabelece objetivos para as aulas e sobre o que os alunos devem aprender até o final da disciplina (Prepara e segue o currículo/plano de ensino e tem objetivos para cada aula).

10. Flexível/aberto(a) a mudanças (Altera o cronograma da disciplina quando necessário; reúne-se com os alunos fora do horário de trabalho quando necessário; presta atenção aos alunos quando expressam opinião; aceita críticas de terceiros; permite que o aluno faça algum trabalho para recuperação de notas quando apropriado).

11. Bom(a) ouvinte (Não interrompe os alunos quando eles estão falando; mantém contato visual; faz perguntas sobre os comentários dos alunos).

12. Atitude alegre/positiva/bem-humorado(a) (Conta piadas e histórias engraçadas; ri com os alunos).

13. Humilde (Admite erros; não se gaba/vangloria; não assume o crédito pelo sucesso dos outros).

14. Domina o tema ensinado (Responde às perguntas dos alunos com facilidade; ao ministrar aulas, não se limita a ler diretamente de livros ou anotações; utiliza exemplos claros e compreensíveis).

15. Preparado(a) (Traz os materiais necessários para a aula; dificilmente se atrasa para a aula; fornece diretrizes para as discussões em classe).

16. Apresenta informações atuais (Relaciona o assunto a situações reais da atualidade; utiliza vídeos, revistas e jornais recentes para demonstrar o que está explicando; fala sobre tópicos atuais; utiliza textos novos ou recentes).

17. Apresentação profissional/postura formal (Veste-se bem [sapatos, calças, blusas, vestidos e camisas limpos e arrumados]; não fala obscenidades). 
18. Promove discussões em aula (Faz perguntas controversas/polêmicas ou desafiadoras durante a aula; quando adequado, dá pontos/nota para participação em aula; envolve os alunos em atividades em grupo durante as aulas).

19. Promove pensamento crítico/intelectualmente estimulante (Em aula, faz perguntas que provocam reflexão; utiliza questões dissertativas em provas e questionários; estabelece tarefas para serem realizadas em casa; realiza discussões/atividades de grupo).

20. Fornece feedback construtivo (Escreve comentários nos trabalhos que recebe dos alunos; responde às perguntas dos alunos; oferece orientações sobre como fazer provas; explica/justifica para o aluno a nota da prova).

21. Pontual/sabe administrar o tempo da aula (Chega à sala de aula no horário ou mais cedo; termina a aula no horário; seleciona e apresenta material relevante nas aulas; separa tempo de aula para perguntas; cumpre os compromissos; devolve os trabalhos em tempo hábil).

22. Estabelece vínculo com os alunos (Faz a turma rir com piadas e histórias divertidas; inicia e mantém discussões em aula; sabe o nome dos alunos; interage com os alunos antes e depois das aulas).

23. Possui expectativas realistas sobre os alunos/avalia e atribui notas justas (Os tópicos a serem avaliados são trabalhados em aula; faz perguntas relevantes na prova; não sobrecarrega os alunos com leitura; ensina em um nível apropriado à maioria dos alunos do curso; se necessário, modifica o valor das notas dos alunos a partir de critérios justos).

24. Respeitoso(a) (Não humilha ou constrange os alunos em aula; é educado(a) com os alunos [diz obrigado e por favor, etc.]; não interrompe os alunos enquanto estão falando; não desvaloriza os alunos).

25. Sensível e persistente (Assegura-se de que os alunos tenham entendido um conteúdo antes de seguir para o próximo; oferece aulas extras; repete as informações quando necessário; faz perguntas para avaliar o entendimento dos alunos).

26. Busca ser um(a) professor(a) melhor (Solicita avaliações dos alunos sobre suas habilidades como professor(a); busca aprendizado/aperfeiçoamento contínuo [participa de seminários, etc. sobre educação]; utiliza novos métodos de ensino).

27. Tecnologicamente competente (Sabe utilizar um computador e softwares para criar e editar textos, planilhas e slides; sabe trocar e-mails com os alunos; sabe utilizar projetores/data show durante a aula; sabe utilizar redes sociais ou recursos disponíveis na internet como ferramentas de apoio às suas aulas).

28. Compreensivo(a) (Aceita justificativas fundamentadas/razoáveis de alunos que faltaram à aula ou não fizeram algum trabalho; está disponível antes ou depois das aulas para responder perguntas; não perde a paciência com os alunos; dedica mais tempo para discutir conceitos difíceis).

Fonte: Adaptado de Keeley, Smith e Buskist (2006).

Nota.

A publicação da versão adaptada para o português do Teacher Behavior Checklist (TBC) no periódico Paidéia (Ribeirão Preto) foi autorizada em 01 de outubro de 2020 via e-mail do Dr. Aaron S. Richmond, editor do periódico Teaching of Psychology, à Comissão Editorial de Paidéia (Ribeirão Preto). O Teacher Behavior Checklist (TBC) foi originalmente publicado em inglês no periódico Teaching of Psychology. Referência completa do artigo original em inglês:

Keeley, J. W., Smith, D., \& Buskist, W. (2006). The Teacher Behaviors Checklist: Factor analysis of its utility for evaluating teaching. Teaching of Psychology, 33(2), 84-91. doi:10.1207/s15328023top3302_1

Note.

The publication of the adapted Portuguese version of the Teacher Behavior Checklist (TBC) in Paidéia (Ribeirão Preto) was authorized on October 1, 2020 by e-mail from Dr. Aaron S. Richmond, editor of the journal Teaching of Psychology, to Paidéia (Ribeirão Preto) Editorial Commission. The Teacher Behavior Checklist (TBC) was originally published in English in the Teaching of Psychology journal. Complete reference of the original article in English:

Keeley, J. W., Smith, D., \& Buskist, W. (2006). The Teacher Behaviors Checklist: Factor analysis of its utility for evaluating teaching. Teaching of Psychology, 33(2), 84-91. doi:10.1207/s15328023top3302_1

Permissão para uso do instrumento:

Não há necessidade de solicitar permissão para o uso do presente instrumento. É exigido, contudo, que o devido crédito seja concedido aos seus autores. O presente artigo deve ser utilizado para a citação do instrumento, e esta nota assegura a permissão para sua utilização. 